\title{
STRATEGI PENJUALAN PRODUK PELUMAS PT PPA DENGAN MENGGUNAKAN ANALISIS SWOT
}

\author{
Yosep Sulindra \\ Program Studi Magister Manajemen Universitas Tarumanagara \\ sulindra.yosep@gmail.com \\ Eddy Herjanto \\ Program Studi Magister Manajemen Universitas Tarumanagara
}

Masuk : 06-11-2020, revisi : 16-12-2020 diterima untuk diterbitkan : 17-12-2020

\begin{abstract}
The purpose of this research is to identify internal factors (strength and weakness) and external (opportunity and threat), formulate alternative sales strategy of PT Perusahaan Pelumas Amerika (PPA)'s lubricants product, and understand differentiation factors of PT PPA compared with competitors. The output of internal audit are strengths and weaknesses and the output of external audit are opportunities and threats. Alternative strategy obtained from matching internal and external factor by using SWOT matrix. By using Quantitative Strategic Planning Matrix (QSPM) to get and implement the best sales strategy for company. Data sources for this research are primary data via interview with senior management officers and secondary data from company website, journal, textbook, and newspaper. Based on analysis method, the priority sales strategy that need to be implemented by company is market penetration with introducing and promote the concept of Total Cost of Ownership (TCO) to potential industrial customer with publication such as seminar, workshop, trade fair, and product knowledge so that PT PPA convince potential customer by providing quality product and added value services to support reaching customer's objectives of reducing overall costs.
\end{abstract} Keywords: IFE Matrix, EFE Matrix, SWOT Matrix, QSPM, TCO

Abstrak: Tujuan penelitian ini adalah untuk mengindentifikasi kondisi internal (kekuatan dan kelemahan) dan eksternal (kesempatan dan ancaman), merumuskan formulasi strategi penjualan produk pelumas PT Perusahaan Pelumas Amerika (PPA), dan memahami faktor pembeda (diferensiasi) PT PPA dengan pesaing merek lain. Hasil dari audit lingkungan internal berupa kekuatan dan kelemahan perusahaan dan hasil dari audit lingkungan eksternal berupa peluang dan ancaman perusahaan. Strategi alternatif diperoleh dengan mencocokkan antara faktor internal dan faktor eksternal menggunakan matriks SWOT. Quantitative Strategic Planning Matrix (QSPM) digunakan untuk memperoleh strategi penjualan yang terbaik pada perusahaan. Sumber data terdiri dari data primer melalui wawancara dengan narasumber dari pihak internal perusahaan dan data sekunder diperoleh berdasarkan situs perusahaan, jurnal, buku, dan surat kabar yang berhubungan dengan penelitian. Dari hasil metode analisis, strategi penjualan yang perlu untuk diimplementasikan perusahaan adalah penetrasi pasar dengan memperkenalkan dan mempromosikan konsep Total Cost of Ownership (TCO) kepada calon pelanggan industri melalui publikasi seperti seminar, workshop, pameran dagang, dan presentasi produk sehingga PT PPA meyakinkan calon pelanggan dengan produk yang berkualitas dan sistem pelayanan yang berfokus pada sisi penghematan bagi pelanggan

Kata Kunci: Matriks IFE, Matriks EFE, Matriks SWOT, QSPM, TCO

\section{PENDAHULUAN}

Salah satu sektor industri strategis yang menarik untuk diteliti adalah pelumas. Penggunaan pelumas adalah untuk mengurangi gesekan, membersihkan komponen mesin, dan mencegah timbulnya karat atau korosi. Mesin industri dan otomotif dalam beroperasi sangat 
memerlukan pelumas. Permintaan akan produk pelumas dipengaruhi oleh dua sektor utama yaitu industri dan transportasi. Kawasan Asia Pasifik seperti China, India, dan Indonesia merupakan pangsa pasar terbesar untuk industri pelumas. Dengan jumlah populasi terbesar disertai dengan pertumbuhan sektor industri dan pembangunan infrastruktur yang masif menyebabkan kawasan ini menjadi target pasar yang ideal bagi industri pelumas. Sektor transportasi turut berkontribusi dalam permintaan pelumas seiring dengan pertambahan jumlah kendaraan bermotor dan peningkatan kebutuhan pelumas untuk transportasi di China, India, dan ASEAN (Grand View Research,2020).

Pada tahun 2020 diperkirakan nilai penjualan global minyak pelumas sebesar USD 157,6 milyar dan proyeksi pada tahun 2025 mencapai angka penjualan sebesar USD 182,6 milyar dengan tingkat pertumbuhan tahunan (CAGR) sebesar 3\% (marketsandmarkets,2020).

Industri manufaktur berperan penting dalam pertumbuhan ekonomi Indonesia. Pertumbuhan industri manufaktur tahun 2019 naik sebesar 4,01\% terhadap tahun 2018 (BPS,2020). Namun di tahun 2020 terjadi perlambatan kegiatan usaha manufaktur dan kelesuan ekonomi tidak hanya di Indonesia melainkan juga di negara-negara lain akibat wabah pandemi Covid-19. Lockdown yang dilakukan di sejumlah negara dan pemberlakuan kembali Pembatasan Sosial Berskala Besar (PSBB) menyebabkan penurunan aktivitas ekonomi hampir di seluruh sektor kecuali pertanian dan informasi komunikasi. Hal ini berdampak pada konsumsi pelumas pada sektor industri dan transportasi. Secara perlahan-lahan pemerintah mulai menerapkan kehidupan normal yang baru untuk menyelamatkan perekonomian dari keterpurukan dengan tetap mematuhi protokol kesehatan.

Peningkatan pertumbuhan pada industri manufaktur di Indonesia menyebabkan pesatnya industri pelumas. Tren pertumbuhan konsumsi pelumas tiap tahun meningkat akibat dari peningkatan kapasitas produksi pabrik dan penjualan otomotif. Kondisi ini menarik banyak perusahaan untuk masuk ke dalam industri pelumas sehingga persaingan menjadi semakin ketat. Pelanggan memiliki banyak alternatif piihan merek pelumas dengan harga yang lebih murah. Padahal pelumas dengan harga murah belum tentu memberikan benefit yang lebih baik daripada pelumas dengan harga mahal. Hal inilah yang menjadi tantangan bagi PT PPA yang merupakan anak perusahaan dari perusahaan energi global yang berbasis di Amerika Serikat untuk mampu bersaing dengan harga yang tergolong mahal. Karena itu, diperlukan strategi penjualan yang tepat sehingga PT PPA dapat meningkatkan penjualan produk pelumas ke pelanggan industri (B2B).

Salah satu analisis yang digunakan dalam penelitian ini adalah matriks SWOT yang dilakukan terlebih dahulu dengan menganalisis kekuatan dan kelemahan internal dan peluang serta ancaman eksternal. Melalui matriks SWOT diperoleh alternatif strategi yang memanfaatkan peluang yang baru dan mengatasi kelemahan dan ancaman bagi PT PPA. Dari tahap-tahap tersebut menjadi dasar dalam pembuatan matriks QSPM untuk memperoleh strategi alternatif penjualan yang terbaik bagi PT PPA.

\section{Tujuan Penelitian}

Tujuan dari penelitian ini adalah untuk menganalisis lingkungan internal dan lingkungan eksternal usaha pelumas PT PPA, merumuskan alternatif strategi penjualan dan memilih strategi alternatif yang terbaik dengan menggunakan matriks QSPM serta mengetahui faktor pembeda (diferensiasi) penjualan pelumas PT PPA yang tidak dimiliki oleh para pesaing.

\section{TINJAUAN PUSTAKA}

PT PPA merupakan perusahaan energi yang berdiri pada tahun 2003 dan salah satu anak perusahaan dari perusahaan energi global terkemuka yang berbasis di Amerika Serikat. Kegiatan usaha PT PPA berfokus pada pemasaran dan distribusi produk pelumas di Indonesia. Seiring dengan berjalannya waktu, perusahaan mengembangkan bisnis pada pemasaran produk kimia dan bahan bakar untuk sektor retail dan industri.

PT PPA memiliki visi dan misi sebagai berikut: 
Visi: menjadi perusahaan terpecaya di bidang energi, yang dikenal akan merek global, dengan teknologi termuktahir, keunggulan operasional, dan struktur keuangan yang kuat.

Misi: menggunakan keahlian, kemampuan, dan dedikasi sumber daya manusianya untuk memberikan manfaat bagi pelanggan, masyarakat, dan pemegang saham baik saat ini, besok, dan selamanya (Cui, Setiawan, Seng, \& Kusniarto, 2017).

Dalam jurnal ini akan dibahas mengenai kekuatan dan kelemahan utama dalam fungsifungsi internal PT PPA, kesempatan dan ancaman yang dihadapi PT PPA berdasarkan evaluasi lingkungan eksternal PT PPA yang tidak dapat dikontrol oleh perusahaan (Pearce \& Robinson,2013). Dengan mengetahui posisi internal dan eksternal, PT PPA dapat mengidentifikasi dan mengevaluasi aspek-aspek yang perlu diperbaiki atau ditingkatkan selain dapat memanfaatkan kesempatan dan menghindari ancaman.

Berdasarkan hasil analisis lingkungan internal perusahaan berupa kekuatan dan kelemahan dan lingkungan eksternal yaitu kesempatan dan ancaman maka dapat dikembangkan matriks SWOT dengan mencocokkan faktor internal dan eksternal kunci maka diperoleh formulasi strategi SO, WO, ST, dan WT.

Matriks Internal Eksternal (IE) memberikan gambaran posisi PT PPA dalam tampilan sembilan sel. Matriks IE didasarkan oleh dua dimensi kunci yaitu skor total tertimbang IFE pada sumbu $x$ dan skor total tertimbang EFE pada sumbu y. Dengan memasukkan skor IFE dan EFE ke dalam matriks IE maka dapat ditentukan strategi perusahaan ke depannya sehingga perusahaan dapat melakukan perencanaan dalam menghadapi para pesaing yang semakin banyak bermunculan di pasar dengan menawarkan harga yang lebih murah daripada harga pelumas PT PPA.

Matriks QSPM mengindikasikan strategi alternatif yang terbaik. QSPM menggunakan input dari analisis matriks EFE dan matriks IFE serta dengan matriks SWOT dan matriks IE memberikan informasi yang dibutuhkan untuk membuat QSPM. Keputusan strategis yang terbaik bagi PT PPA mempertimbangkan semua faktor internal dan eksternal yang saling mempengaruhi (David \& David, 2015). Dengan menerapkan strategi penjualan yang terbaik bagi PT PPA maka perusahaan perlu melakukan penyesuaian strategi bisnis apalagi di tengah pandemi Covid-19 mengharuskan perusahaan untuk adaptif terhadap perubahan perilaku baru pasar dengan memanfaatkan perkembangan teknologi (Kompas, 2020).

Salah satu tantangan utama yang dihadapi PT PPA dalam memperkenalkan produk pelumas dan dalam upaya meningkatkan pangsa pasar adalah keputusan pembelian ditentukan berdasarkan harga paling murah padahal merek dengan harga yang lebih murah tersebut belum tentu memberikan benefit yang lebih besar. Ini menjadi tugas dan tanggung jawab PT PPA dalam mengedukasi pelanggan bahwa dengan melakukan investasi awal (harga beli) yang tinggi pada akhirnya untuk efek jangka panjang pelanggan memperoleh benefit dan penghematan yang jauh lebih besar.

Sikap resistensi user terhadap produk pelumas PT PPA turut mempengaruhi penjualan PT PPA karena user sudah terbiasa menggunakan pelumas existing dan timbul kekhawatiran apabila diganti dengan merek pelumas lain akan berpotensi menimbulkan masalah di mesin. Hal ini tidaklah mudah untuk menyakinkan user yang sudah merasa nyaman dengan kondisi saat ini. Dengan demikian berbekal reputasi merek yang sudah terkenal dan pengalaman ratusan tahun di bidang pelumas industri menjadi modal berharga dalam melakukan penetrasi pasar dan memberikan edukasi atau pelatihan kepada user untuk meningkatkan wawasan akan teknologi pelumasan serta pentingnya pelumas yang berkualitas yang sesuai dengan aplikasi.

\section{METODOLOGI PENELITIAN}

Jenis penelitian yang digunakan adalah penelitian kualitatif yang bertujuan untuk mendeskripsikan fakta-fakta yang sebenarnya terkait kondisi internal dan eksternal pada PT PPA. Data penelitian ini diperoleh dari dua sumber yaitu (Sekaran \& Bougie, 2017): 
a. Data primer dengan melakukan wawancara dengan empat narasumber kunci dari PT PPA untuk memperoleh informasi mengenai audit internal. Keempat narasumber tersebut adalah Direktur Utama, General Manager B2B, Regional Sales Manager Wilayah Jawa dan Timur

b. Data sekunder diperoleh dengan studi literatur dari buku, catatan-catatan PT PPA, surat kabar, dan data yang diperoleh dari internet seperti data Badan Pusat Statistik (BPS) dan Kementerian Perindustrian Metode analisis yang digunakan dalam penelitian ini yaitu:

a. Analisis lingkungan terdiri dari analisis lingkungan internal berupa kekuatan dan kelemahan perusahaan dan analisis lingkungan eksternal berupa peluang dan ancaman

b. Analisis strategi yaitu matriks SWOT dan matriks internal eksternal (IE) yang mencocokkan kekuatan dan kelemahan internal PT PPA dengan peluang dan ancaman eksternal dan diperoleh berbagai strategi alternatif

c. Tahap keputusan dengan menggunakan teknik Quantitative Strategic Planning Matrix (QSPM) untuk memperoleh strategi alternatif yang terbaik. QSPM berdasarkan pada input dari analisis lingkungan eksternal dan internal dan pencocokkan hasil dari matriks SWOT dan matriks IE

\section{HASIL DAN KESIMPULAN}

Dari analisis SWOT diperoleh hasil bahwa PT PPA memiliki kekuatan utama yaitu integritas produk yang terdiri atas kualitas produk, kinerja, dan memperhatikan aspek lingkungan hidup dan konsisten memberikan kualitas layanan yang unggul dibandingkan dengan para pesaing sehingga pelanggan memperoleh cost savings dan jaminan kualitas produk pelumas PT PPA. Kelemahan utama PT PPA adalah harga jual produk yang relatif mahal mengingat pembeli Indonesia mengutamahan harga semurah-murahnya tanpa memperhitungkan keuntungan jangka panjang, cakupan wilayah distribusi yang masih terbatas, dan waktu pengiriman untuk beberapa produk tertentu lama tiba di pabrik pelanggan.

PT PPA memiliki peluang terhadap pertumbuhan industri manufaktur, potensi industri yang besar di kawasan Indonesia bagian timur seperti industri pertambangan dan pengolahan bijih mineral (smelter), pengembangan pelumas sintetik untuk mesin-mesin berteknologi tinggi, dan perubahan perilaku baru konsumen akibat dampak pandemi Covid-19 menimbulkan peluang bisnis untuk meningkatkan volume penjualan. Namun, ancaman yang dihadapi PT PPA adalah pesaing yang semakin banyak dan harga yang ditawarkan pesaing relatif lebih murah. Faktor harga masih menjadi faktor utama dalam keputusan pembelian pelanggan sehingga merupakan tantangan bagi PT PPA untuk menyakinkan dan mendapatkan kepercayaan dari pelanggan.

Dari matriks SWOT diperoleh hasil formulasi strategi yaitu strategi SO meliputi konsistensi peningkatan layanan kepada pelanggan industri, melakukan penawaran program continuous improvement kepada pelanggan industri, memanfaatkan kerjasama tim yang solid dan pengalaman perusahaan untuk memperluas segmen pasar ke industri logistik, peneltian dan pengembangan produk pelumas untuk kendaraan listrik/tanpa emisi serta mendukung program pemerintah yang mewajibkan aktivitas operasional industri pertambangan menggunakan biodiesel B30

Strategi WO meliputi menjalin kerjasama dengan distributor baru dan melakukan akuisisi perusahaan lokal untuk menjangkau wilayah distribusi yang lebih luas, melakukan perjanjian kerja sama dengan PLN untuk pengadaan pelumas turbin pembangkit listrik energi terbarukan, serta meningkatkan kegiatan pemasaran via internet yang memudahkan pengguna mencari informasi produk dan langsung memesan produk secara online 24 jam

Strategi ST meliputi mengikuti pameran dagang dan mengadakan seminar atau workshop supaya kalangan industri lebih memahami potensi improvement dari penggunaan produk pelumas PT PPA, melakukan strategi cadangan stock bahan baku base oil dan aditif untuk 
mengantisipasi lonjakan harga yang diakibatkan oleh supply-demand dan situasi politik, menjamin kualitas produksi pelumas tanpa cacat sesuai persyaratan OEM, dan mendukung program pemerintah menuju revolusi industri 4.0 dengan kapabilitas PT PPA dalam pengembangan pelumas berkinerja tinggi (pelumas sintetik) untuk proses otomasi mesin

Strategi WT meliputi menjalin kerjasama dengan perusahaan pembuat mesin dan peralatan industri (OEM), meningkatkan frekuensi kunjungan tim sales dan technical support ke pabrik pelanggan untuk memberikan respons cepat terhadap keluhan atau permasalahan yang terjadi pada mesin, memantau kondisi mesin, melakukan penawaran produk dan presentasi produk serta mencegah peredaran oli palsu dan produk cacat atau terkontaminasi di pasaran untuk menjaga kualitas produk dan mencegah kerugian yang dialami pelanggan. PT PPA juga bisa menggunakan hak kekayaan intelektual dan hukum internasional bagi siapa saja pihak yang terlibat dalam peredaran oli palsu.

Matriks IE menempatkan posisi PT PPA dalam sel strategi berikut:

a. Penetrasi pasar

Memperkenalkan konsep Total Cost of Ownership (TCO) melalui usaha publikasi (seminar/webinar/workshop/presentasi produk) dan dokumentasi benefit

b. Pengembangan produk

Meluncurkan produk terbaru pelumas industri dengan formulasi yang telah ditingkatkan untuk memenuhi kebutuhan akan pelumas berkualitas tinggi yang sesuai dengan spesifikasi atau rancangan pembuat mesin (OEM/engine builder)

Kesimpulan yang diperoleh berdasarkan hasil penelitian yaitu kekuatan utama PT PPA adalah reputasi merek global yang sudah diakui dunia, integritas produk yang terdiri atas kualitas produk, garansi kinerja, dan memperhatikan aspek lingkungan hidup dan melengkapi dengan pelayanan bagi kepuasan pelanggan yang didukung oleh kerjasama tim internal yang berkualifikasi dan berpengalaman di bidang pelumas. Kelemahan utama PT PPA adalah harga jual produk yang mahal, cakupan distribusi yang masih terbatas, dan waktu pengiriman yang lama untuk beberapa produk tertentu.

PT PPA memiliki peluang terhadap pertumbuhan industri manufaktur, potensi industri yang besar di kawasan Indonesia bagian timur, pengembangan pelumas sintetik untuk mesinmesin berteknologi tinggi, dan perubahan perilaku baru pasar sebagai akibat dari pandemi Covid-19 sedangkan ancaman PT PPA adalah intensitas persaingan yang semakin meningkat dan harga yang ditawarkan pesaing relatif lebih murah. Faktor harga masih menjadi faktor utama dalam keputusan pembelian pelanggan sehingga merupakan tantangan bagi PT PPA untuk meyakinkan dan mengedukasi calon pelanggan akan potensi penghematan atas penggunaan produk pelumas PT PPA pada mesin-mesin industri.

Faktor pembeda (diferensiasi) yang dimiliki PT PPA adalah komitmen terhadap kualitas produk dan sistem pelayanan yang berfokus pada nilai tambah (added value) berupa penghematan. Bagi PT PPA harga merupakan prioritas kedua. Di zaman sekarang ini tidak cukup hanya mengandalkan harga lebih murah namun diperlukan produk yang berkualitas disertai dengan pelayanan. Walaupun pesaing mencoba meniru sistem pelayanan PT PPA, masih terdapat kekurangan di dalam melakukan perhitungan penghematan karena tidak semua pesaing mampu dan bersedia untuk menghitung TCO karena keterbatasan kompetensi sumber daya manusia dan tambahan biaya. Pelayanan yang buruk menimbulkan kesan yang kurang menyenangkan bagi pelanggan sehingga pelanggan dengan mudah beralih ke merek lain (Tjiptono,2019).

Berdasarkan hasil analisis matriks QSPM keputusan strategi yang paling baik dan lebih diutamakan bagi PT PPA adalah melakukan strategi penetrasi pasar melalui peningkatan usaha promosi konsep Total Cost of Ownership (TCO) dan potensi penghematan produk ke pelanggan. 


\section{DAFTAR PUSTAKA}

Badan Pusat Statistik. (2020). Pertumbuhan produksi IBS tahun 2019 naik 4,01 persen dibandingkan tahun 2018. Retrieved April 5, 2020, from http://www.bps.go.id

Cui, C., Setiawan, B., Seng, L., \& Kusniarto, A. (2017). Sinarmas Pulp \& Paper Lubricant Solutions Proposal. Jakarta: PT Perusahaan Pelumas Amerika (PPA)

David, F. R. \& David, F. R. (2015). Strategic Management Concept and Cases (15 ${ }^{\text {th }}$ ed.). Harlow, England: Pearson Education Limited

Grand View Research, Inc. (2020). Lubricants Market Size, Share \& Trends Analysis Report by Application (Industrial, Automotive, Marine, Aerospace), by Region (North America, Europe, APAC, Latin America, MEA), and Segment Forecast 2020-2027. Retrieved December 14, 2020, from https://www.grandviewresearch.com/industryanalysis/lubricants-market

MarketsandMarkets Research Private Ltd. (2020). Lubricants Market by Base Oil (Mineral Oil, Synthetic Oil, Bio-based Oil), Product Type (Engine Oil, Hydraulic Fluid, Metalworking Fluid),Application (Transportation and Industrial lubricants), Region Global Forecast to 2025. Retrieved August 19, 2020, from https://www.marketsandmarkets.com/Market-Reports/lubricantsmarket182046896.html

Pearce, J. A. \& Robinson, R. B. (2013). Manajemen Strategis (12 ${ }^{\text {th }}$ ed.). Jakarta: Penerbit Salemba Empat.

Pemulihan Ekonomi Nasional: Pelaku Usaha Perlu Merespons Perilaku Baru Pasar. (2020, 20 Oktober). Kompas. h.10

Sekaran, U. \& Bougie, R. (2017). Metode Penelitian untuk Bisnis (6 $6^{\text {th }}$ ed.). Jakarta: Penerbit Salemba Empat.

Tjiptono, F. (2019). Strategi Pemasaran ( $4^{\text {th }}$ ed). Yogyakarta: Penerbit Andi. 